\title{
Ghrelin-induced GH secretion in domestic fowl in vivo and in vitro
}

\author{
M-L Baudet and S Harvey \\ Department of Physiology, University of Alberta, Edmonton, Alberta T6 G 2H7, Canada \\ (Requests for offprints should be addressed to S Harvey; Email: steve.harvey@ualberta.ca)
}

\section{Abstract}

Although avian and mammalian species differ significantly in their regulation of $\mathrm{GH}$ secretion, preliminary studies have demonstrated in vivo GH responses to ghrelin in chickens, as in mammals. However, the relative potency of ghrelin as a GH-releasing hormone (GHRH) in birds is uncertain, as is its site of action.

The intravenous administration of human ghrelin to immature chickens promptly increased the circulating $\mathrm{GH}$ concentration (within $10 \mathrm{~min}$ ), although this was transitory and was only maintained for $20 \mathrm{~min}$. This $\mathrm{GH}$ response was dose-related with an $\mathrm{EC}_{50}$ of approximately $3 \cdot 0 \mu \mathrm{g} / \mathrm{kg}$, comparable with the reported potency of human GHRH in chickens. When incubated with dispersed pituitary cells, human ghrelin induced dosedependent $\mathrm{GH}$ release over a range of $10^{-6}$ to $10^{-9} \mathrm{M}$, with an $\mathrm{EC}_{50}$ of $7 \cdot 0 \times 10^{-8} \mathrm{M}$, comparable with that induced by human GHRH $\left(\mathrm{EC}_{50} 6 \cdot 0 \times 10^{-8} \mathrm{M}\right)$,
\end{abstract}

although it was less effective at doses of $10^{-6}$ to $10^{-8} \mathrm{M}$. This was due to direct effects on pituitary somatotrophs, since human ghrelin increased GH release (determined by the reverse hemolytic plaque assay) from individual pituitary cells. The incubation of these cells with human ghrelin induced a dose-dependent increase in the numbers of somatotrophs secreting $\mathrm{GH}$ and in the amount of $\mathrm{GH}$ released by each cell.

In summary, these results demonstrated that ghrelin is a dose-related GH-releasing factor in chickens with a potency comparable with that induced by human GHRH. The GH-releasing action of ghrelin is due, at least in part, to stimulatory actions on the numbers of somatotrophs induced to release $\mathrm{GH}$ and upon the amount of $\mathrm{GH}$ released from individual somatotrophs.

Journal of Endocrinology (2003) 179, 97-105

\section{Introduction}

The discovery that ghrelin is the endogenous ligand of the growth hormone $(\mathrm{GH})$ secretagogue receptor (Kojima et al. 1999) led to a re-evaluation of the neuroendocrine regulation of GH secretion (Kojima et al. 2001). Indeed, ghrelin was shown to strongly stimulate $\mathrm{GH}$ release in humans (Arvat et al. 2000, Peino et al. 2000, Takaya et al. 2000), in whom it was found to be more potent than $\mathrm{GH}$-releasing hormone (GHRH) in vivo (Arvat et al. 2000, 2001). It is also more effective than GHRH in stimulating in vivo GH release in rats (Seoane et al. 2000, Tolle et al. 2001), although its GH-releasing activity in vitro is only comparable with (Kojima et al. 1999) or less than (Yamazaki et al. 2002, Pinilla et al. 2003) that induced by GHRH.

The hypothalamic regulation of $\mathrm{GH}$ secretion in birds differs significantly from that in mammals (Harvey 1993a), but ghrelin has recently been shown to increase plasma $\mathrm{GH}$ concentrations in immature chickens, although not (as yet) in a dose-related way (Ahmed \& Harvey 2002, Kaiya et al. 2002). The in vivo potency of ghrelin in birds is thus unknown, as is its possible site of action. Although ghrelin directly stimulates $\mathrm{GH}$ release from mammalian pituitary cells (Kojima et al. 1999, Yamazaki et al. 2002), it also has hypothalamic sites of action (Date et al. 2000, Tannenbaum \& Bowers 2001, Tolle et al. 2001, Tamura et al. 2002, Wren et al. 2002), Moreover, while pituitary sites of ghrelin action have been demonstrated, it is still uncertain if this is due to the direct stimulation of somatotrophs or the stimulation of other cell types that might indirectly regulate somatotroph function. Indeed, other secretagogues are thought to affect pituitary function by inducing paracrine cascades between heterologous cell types (e.g. Robberecht et al. 1992, Tilemans et al. 1992, Schwartz 2000, 2001). The GH-releasing activity of ghrelin has, therefore, been further examined in vivo and in vitro in domestic fowl and direct effects on isolated chicken somatotrophs have been determined.

\section{Materials and Methods}

In vivo experiments

Immature, 4- to 5-week-old White Leghorn cockerels (approximately $400-500 \mathrm{~g}$ ) were injected intravenously 
(into a wing vein) with human ghrelin (031-30; Phoenix Peptides International, Belmond, CA, USA) at doses of $0.03-100 \cdot 0 \mu \mathrm{g} / \mathrm{kg}$ in $0.9 \%(\mathrm{w} / \mathrm{v}) \mathrm{NaCl}$. Controls were similarly injected with the saline vehicle $(1.0 \mathrm{ml} / \mathrm{kg})$. Heparinized blood samples $(0.5-1.0 \mathrm{ml})$ were then collected from the contralateral vein after $10 \mathrm{~min}$ (the time of the maximal $\mathrm{GH}$ response to other $\mathrm{GH}$ secretagogues; Harvey \& Scanes 1984), or at additional intervals (20, 30 and $60 \mathrm{~min}$ ) following injection, in accordance with previous in vivo studies (Harvey et al. 1978, Harvey \& Scanes 1984, Scanes \& Harvey 1984) and in compliance with the University of Alberta's Policy on Animal Welfare. Following centrifugation and separation, the plasma was stored at $-20{ }^{\circ} \mathrm{C}$ prior to $\mathrm{GH}$ radioimmunoassay, using NIADD reagents (Bethesda, MD, USA, kindly provided by Dr A F Parlow), as previously described (Ahmed \& Harvey 2002). Because the blood volume of a chick is approximately $10 \%$ of its body weight and as the birds were killed (by cervical dislocation) at the end of the experiment, plasma was not replaced following blood collection.

\section{In vitro experiments}

Dispersed pituitary cells The GH-releasing activity of human ghrelin was assessed using freshly dispersed pituitary cells, as outlined by Harvey et al. (1978) for the GH-releasing activity of thyrotrophin-releasing hormone $(\mathrm{TRH})$. Briefly, anterior pituitary glands from the heads of 6-week-old broiler fowl (obtained from Lillydale, Edmonton, Alberta, Canada) were collected into ice-cold Medium 199 (Gibco, Burlington, Ontario, Canada) and pituitary cells were obtained after a 2-h incubation at $39^{\circ} \mathrm{C}$ in $0.02 \%(\mathrm{w} / \mathrm{v})$ collagenase (type III, fraction A; Sigma Chemical Company, St Louis, MO, USA). The cells were collected by centrifugation (100 $g$ for $10 \mathrm{~min}$ ) and twice resuspended in fresh media, after filtration through a nylon gauze. The cells were dispersed at a final concentration of 1 pituitary equivalent $/ 0.5 \mathrm{ml}$, using a magnetic stirrer, and $0.5 \mathrm{ml}$ aliquots were dispersed into $2 \mathrm{ml}$ polystyrene tubes, together with the test solutions, dissolved in an equal volume of Medium 199. The resulting cells had a viability of $>95 \%$, as assessed by trypan blue exclusion. The tubes $(n=6$ per group) were then oxygenated with $95 \%(\mathrm{v} / \mathrm{v}) \mathrm{O}_{2}: 5 \%(\mathrm{v} / \mathrm{v}) \mathrm{CO}_{2}$, sealed with parafilm and incubated in a shaking water bath at $39^{\circ} \mathrm{C}$ for $2 \mathrm{~h}$. The tubes were then centrifuged (at $1000 \mathrm{~g}$ for $10 \mathrm{~min}$ at $4{ }^{\circ} \mathrm{C}$ ) and the supernatants collected and stored at $-20{ }^{\circ} \mathrm{C}$ until $\mathrm{GH}$ radioimmunoassay (Ahmed \& Harvey 2002). The sensitivity of the assay was $<1.0 \mathrm{ng}$ $\mathrm{GH} / \mathrm{ml}$ and hence the samples were diluted in radioimmunoassay buffer prior to assay. The GH-releasing activity of human ghrelin (Phoenix Peptides International) was determined at concentrations of $10^{-10}$ to $10^{-6} \mathrm{M}$, in comparison with similar concentrations of human GHRH $_{1-44}$ (Bachem, Torrance, CA, USA), an estab- lished in vitro GH-releasing factor in birds (Harvey 1999). All the samples from these experiments were determined in a single assay to facilitate comparisons of GH-releasing activity.

Individual pituitary cells To ensure that the GHreleasing action of ghrelin in vitro was due to direct effects on pituitary somatotrophs, rather than mediated via actions on other pituitary cell types (Schwartz 2000, 2001), its GH-releasing activity was determined in individual somatotrophs, using the reverse hemolytic plaque assay (RHPA; Neill \& Frawley 1983, Frawley \& Neill 1984). In brief, dispersed pituitary cells $\left(10^{6}\right.$ cells $\left./ \mathrm{ml}\right)$ in Dulbecco's modified Eagle's medium (DMEM; Gibco) containing $0 \cdot 1 \%(\mathrm{w} / \mathrm{v})$ IgG-free bovine serum albumin (Fraction V; Sigma) and antibiotics (penicillin $G$ and streptomycin sulfate (Invitrogen, Burlington, Ontario, Canada), both at $100 \mathrm{U} / \mathrm{ml})$, were mixed with an equal volume of a $20 \%$ $(\mathrm{v} / \mathrm{v})$ suspension of ovine red blood cells (oRBCs) conjugated with Staphylococcus aureus protein-A (Sigma). This mix was then infused by capillary action into $30 \mu \mathrm{l}$ Cunningham chambers, previously constructed on polyL-lysine-coated microscopic slides (Sigma). The cells were allowed to attach as a monolayer $\left(1 \mathrm{~h}\right.$ at $\left.39^{\circ} \mathrm{C}\right)$ in a $5 \%$ $\mathrm{CO}_{2}$ incubator. The chambers were then washed with DMEM to remove all unattached cells. DMEM containing anti-chicken $\mathrm{GH}$ antiserum (1:50; kindly provided by Dr T Porter, University of Maryland, USA) was then infused into the chambers with or without secretagogues (human ghrelin (Phoenix Peptides International) or human $\mathrm{GHRH}_{1-29}$ (Bachem) at a final concentration of $10^{-10}$ to $10^{-6} \mathrm{M}$ ) and the cells were incubated for $60 \mathrm{~min}$, since preliminary studies established that plaqueforming cells are readily detectable at this time. After a wash with DMEM, guinea pig complement (Cedarlane, Ontario, Canada) was then infused into the chambers (at a dilution of 1:120 in DMEM). The cells were fixed, 30 min later, with $2 \%(\mathrm{w} / \mathrm{v})$ glutaraldehyde (Sigma) and stained with toluidine blue to facilitate identification of the large pituitary cells dispersed amongst the smaller oRBCs. Approximately 1000 pituitary cells in each chamber were identified and the percentage of plaque-forming cells was determined using a light microscope. Plaque areas were determined using Image-Pro software (Carsson, Toronto, Ontario, Canada). The specificity of plaque formation was demonstrated by their absence when (i) the GH antiserum or (ii) the guinea pig complement were omitted, or when (iii) the GH antiserum was replaced by normal rabbit serum or (iv) by GH antiserum that had been preabsorbed with excess recombinant chicken $\mathrm{GH}(1 \mathrm{mg} / \mathrm{ml}$ for $2 \mathrm{~h}$; Amgen, Thousand Oaks, CA, USA).

Statistical differences were determined by Student's paired $t$-test or analysis of variance, where appropriate, and data were correlated by linear regression and analyzed for $\mathrm{EC}_{50}$ for dose-response relationships. 


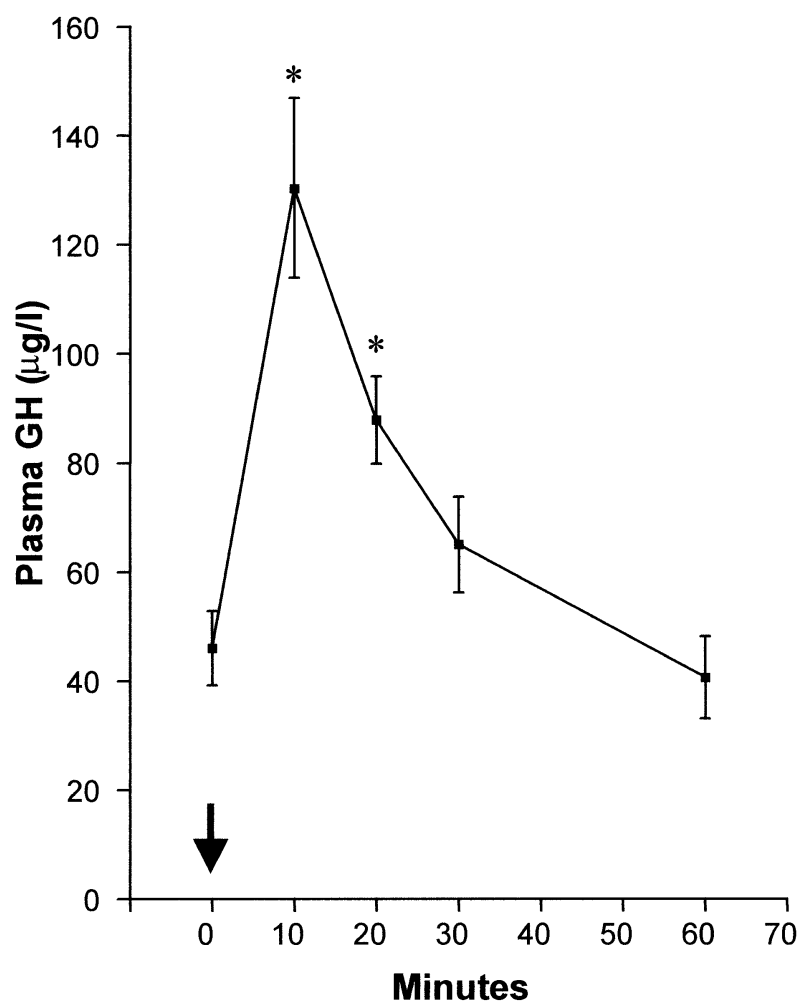

Figure $1 \mathrm{GH}$ concentration in the plasma of 4- to 5-week-old White Leghorn cockerels at intervals after an intravenous injection (indicated by the arrow) of human ghrelin $(10 \mu \mathrm{g} / \mathrm{kg})$. Values are means \pm S.E.M. $(n=8) .{ }^{*} P<0.05$ in comparison with pretreatment concentration (Student's paired $t$-test).

\section{Results}

In vivo experiments

As expected (Ahmed \& Harvey 2002, Kaiya et al. 2002), the plasma $\mathrm{GH}$ concentration in immature chickens was increased $(P<0 \cdot 01)$ almost threefold $10 \mathrm{~min}$ after the intravenous administration of ghrelin, at a dose of $10 \mu \mathrm{g} /$ kg (Fig. 1). The GH concentration remained elevated after $20 \mathrm{~min}(P<0 \cdot 01$, paired Student's $t$-test $)$, but had returned to the pretreatment level by $30 \mathrm{~min}$. In a second study, similar threefold increases in the GH concentration were observed $10 \mathrm{~min}$ after the administration of ghrelin at 10 or $100 \mu \mathrm{g} / \mathrm{kg}(P<0 \cdot 01$ in both cases, in comparison with the concentration $(38 \cdot 3 \pm 4 \cdot 3 \mu \mathrm{g} / \mathrm{l})$ in the vehicleinjected controls; Fig. 2). Lower doses of ghrelin $(1 \mu \mathrm{g} / \mathrm{kg}$ and $3 \mu \mathrm{g} / \mathrm{kg}$ ) also increased the $\mathrm{GH}$ concentration $(P<0 \cdot 05)$, but to levels lower $(P<0 \cdot 05)$ than those induced by the higher doses (analysis of variance). At $0 \cdot 1 \mu \mathrm{g} / \mathrm{kg}$ and $0.3 \mu \mathrm{g} / \mathrm{kg}$, ghrelin had no effect on the plasma GH concentration. The GH concentration $10 \mathrm{~min}$ after ghrelin administration was, therefore, dose-related $(r=0.50(n=72), P<0 \cdot 001)$, with an $\mathrm{EC}_{50}$ of approximately $3 \cdot 0 \mu \mathrm{g} / \mathrm{kg}$.

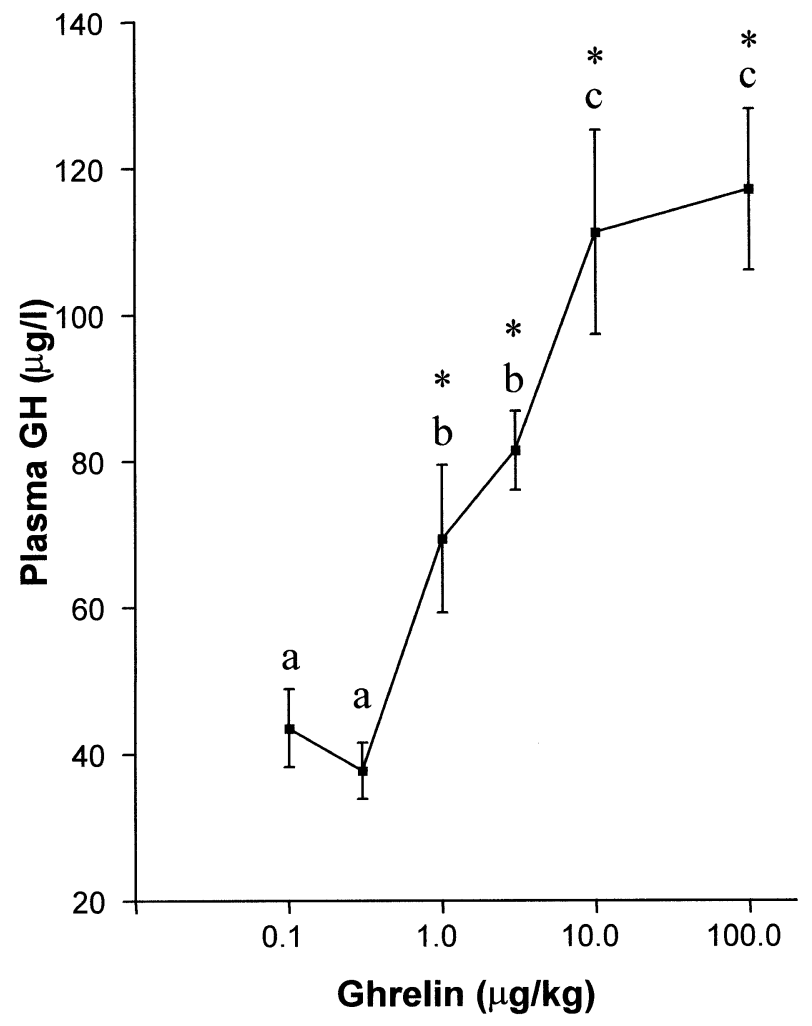

Figure $2 \mathrm{GH}$ concentrations in the plasma of 4- to 5-week-old White Leghorn cockerels $10 \mathrm{~min}$ after an intravenous injection of human ghrelin at concentrations of $0 \cdot 1-100 \mu \mathrm{g} / \mathrm{kg}$. Controls were injected with the $0.9 \%(\mathrm{w} / \mathrm{v}) \mathrm{NaCl}$ vehicle $(1 \mathrm{ml} / \mathrm{kg})$. Values are means \pm S.E.M. $(n=12) .{ }^{*} P<0 \cdot 05$ (analysis of variance) in comparison with the controls $(38 \cdot 3 \pm 4 \cdot 3 \mu \mathrm{g} / \mathrm{l})$. Groups with different letters are significantly different $(P<0 \cdot 05$, analysis of variance).

In vitro experiments

In the absence of a $\mathrm{GH}$ secretagogue, very little $\mathrm{GH}$ $(0.90 \pm 0.04 \mu \mathrm{g} \mathrm{GH} /$ pituitary equivalent per $\mathrm{ml}$; means \pm S.E.M. $(n=6))$ was present in the media of dispersed pituitary cells (data not shown). In marked contrast, the media GH concentration was dramatically increased $(P<0 \cdot 05$, analysis of variance $)$ in the presence of ghrelin at concentrations of $10^{-9}$ to $10^{-6} \mathrm{M}$, although ghrelin was ineffective at a dose of $10^{-10} \mathrm{M}$ (Fig. 3). The GH response was clearly dose-related $(r=0.94 \quad(n=30)$, $P<0 \cdot 001)$ with an $\mathrm{EC}_{50}$ of $7 \cdot 04 \times 10^{-8} \mathrm{M}$. At the same doses, GHRH similarly induced GH release $(r=0.93$ $(n=30), P<0 \cdot 001)$, with an $\mathrm{EC}_{50}$ of $6 \cdot 0 \times 10^{-8} \mathrm{M}$ (Fig. 3). The GH responses to GHRH at $10^{-6}, 10^{-7}$ and $10^{-8} \mathrm{M}$ were greater $(P<0 \cdot 05$, analysis of variance) than those to the same doses of ghrelin (Fig. 3).

Individual $\mathrm{GH}$-secreting cells were identified by the formation of plaques in the RHPA (Fig. 4A-C). Qualitative studies showed that the numbers and sizes of these plaques were increased in the presence of $10^{-6} \mathrm{M}$ 

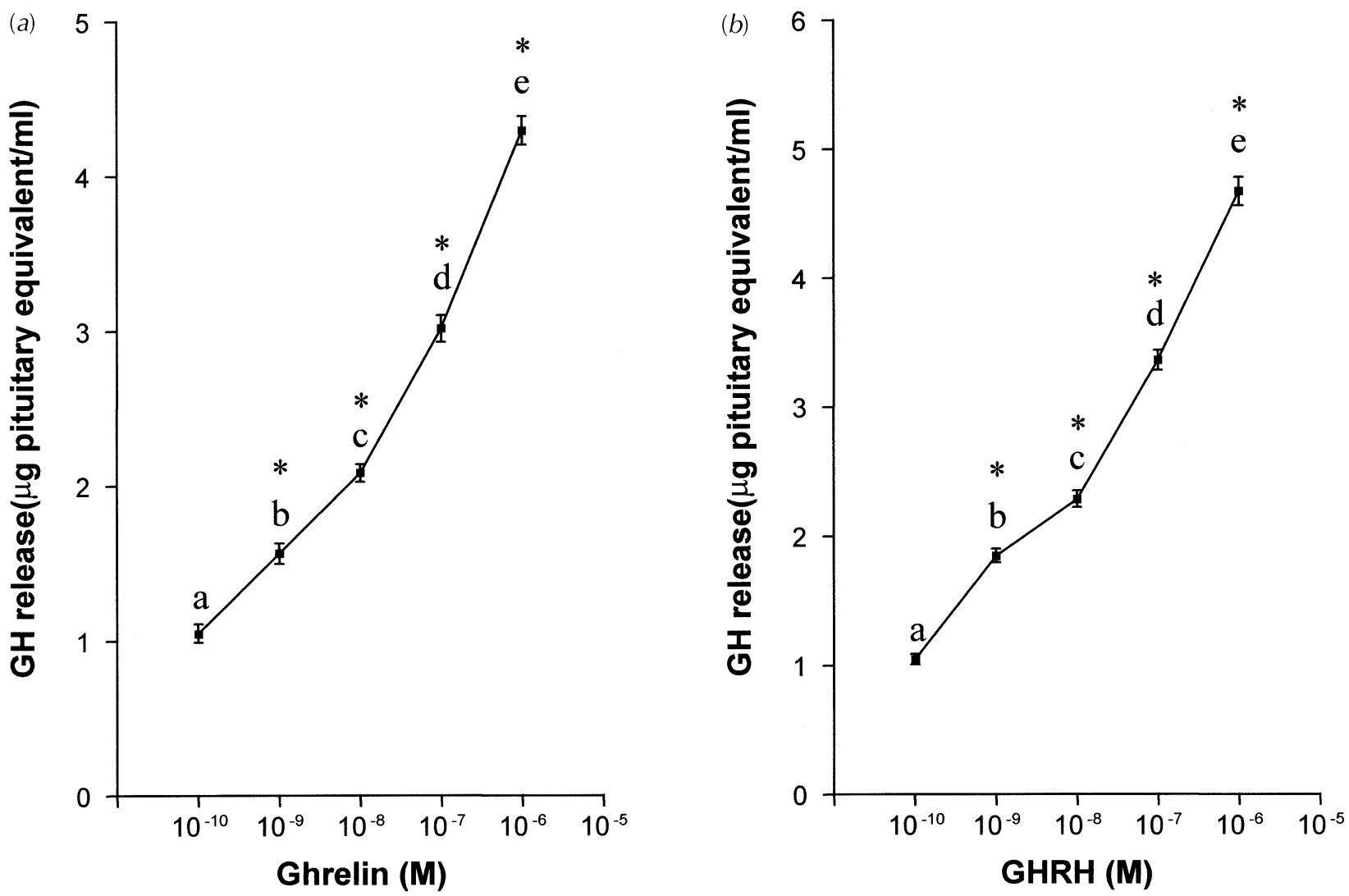

Figure $3 \mathrm{GH}$ released from incubated dispersed pituitary cells (a) in response to human ghrelin and $(b)$ in comparison with human GHRH. Asterisks indicate values significantly different $(P<0.05$, analysis of variance) from the controls $(0.90 \pm 0.04 \mu \mathrm{g}$ pituitary equivalent/ml). Values are means \pm S.E.M. $(n=6)$. Groups with different letters are significantly different $(P<0 \cdot 05$, analysis of variance).

ghrelin (Fig. 4D-F), similar to those induced by $10^{-6} \mathrm{M}$ GHRH (Fig. 4G-I) and $10^{-6} \mathrm{M}$ TRH (Fig. 4J-L). The numbers and sizes of the plaques produced after a $60-\mathrm{min}$ incubation in $10^{-10} \mathrm{M}$ ghrelin (Fig. 5) were not, however, significantly different from those in controls (data not shown). The numbers of the plaques were, however, increased $(P<0 \cdot 05$, analysis of variance $)$ in response to $10^{-9}, 10^{-8}, 10^{-7}$ and $10^{-6} \mathrm{M}$ ghrelin (Fig. 5). This response was dose-related $(r=0.55(n=20), P<0 \cdot 05)$, with an $\mathrm{EC}_{50}$ of approximately $9 \times 10^{-9} \mathrm{M}$. The size of the plaques was also increased $(P<0 \cdot 05$, analysis of variance) with ghrelin at $10^{-7}$ and $10^{-6} \mathrm{M}$ (Fig. 5). The response was also dose-related $(r=0.71(n=20), P<0.05)$, with an $\mathrm{EC}_{50}$ of approximately $4 \times 10^{-8} \mathrm{M}$.

\section{Discussion}

These results demonstrate that ghrelin is a GH secretagogue in chickens with in vivo and in vitro GH-releasing activity.

Human and chicken ghrelin have previously been shown to increase circulating GH concentrations in 8-dayold broiler chicks, at doses of 2 and $10 \mu \mathrm{g}$ (at least

Figure 4 Photomicrographs of plaques from GH-secreting pituitary cells, determined by the RHPA. The plaques are clear zones of lysed oRBCs surrounding large individual pituitary cells. The plaques are produced after GH antiserum (1:50) binds to GH released from the pituitary cells, and lysis of the protein A-conjugated oRBCs occurs in the presence of guinea pig complement (1:120). GH plaques in the absence of secretagogues are shown in (A), (B) and (C) (at magnifications of $\times 50, \times 100$ and $\times 400$ respectively). GH plaques in response to $10^{-6} \mathrm{M}$ ghrelin are shown in (D), (E) and (F) at similar magnifications, whereas $(\mathrm{G}),(\mathrm{H})$ and $(\mathrm{I})$ show $\mathrm{GH}$ plaques induced by $10^{-6} \mathrm{M}$ human GHRH and (J), (K) and (L) show GH plaques produced by $10^{-6} \mathrm{M} \mathrm{TRH}$, also at magnifications of $\times 50, \times 100$ and $\times 400$ respectively. Panels (C), (F), (I) and (L) show individual somatotrophs (arrows) surrounded by 'ghosts' (arrowheads) of lysed oRBCs. Some pituitary cells (chevrons) did not secrete GH under basal and stimulated conditions. 


\section{X50 \\ $\mathrm{X} 100$ \\ $\mathrm{X} 400$}

Basal
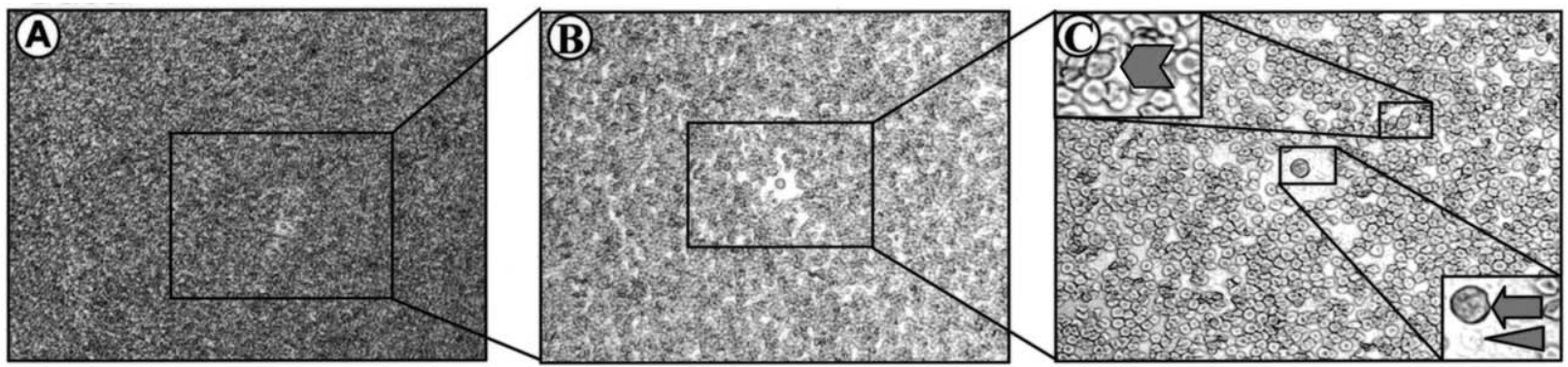

Ghrelin $10^{-6} \mathrm{M}$

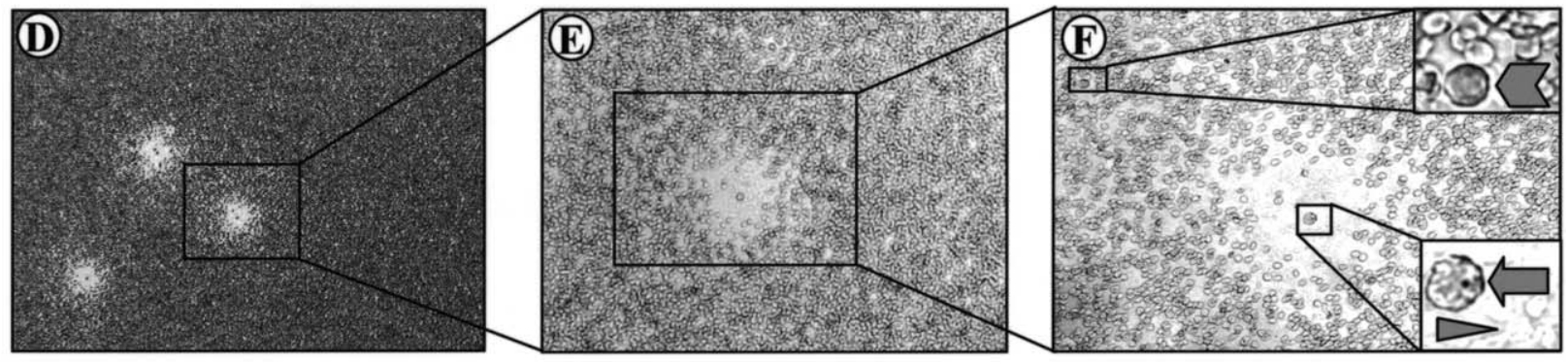

GHRH $10^{-6} \mathrm{M}$
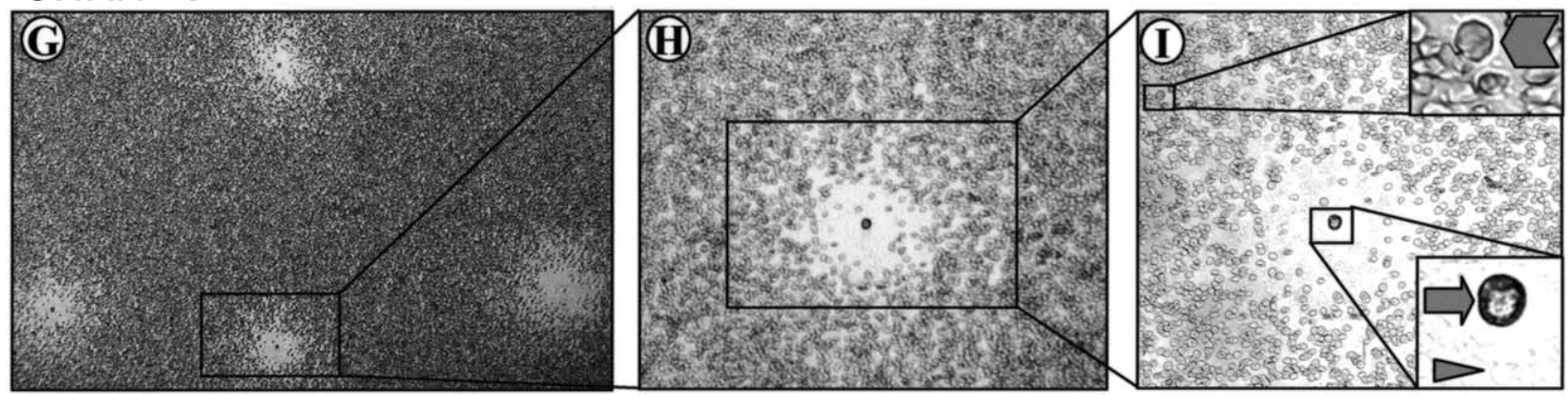

TRH $10^{-6} \mathrm{M}$

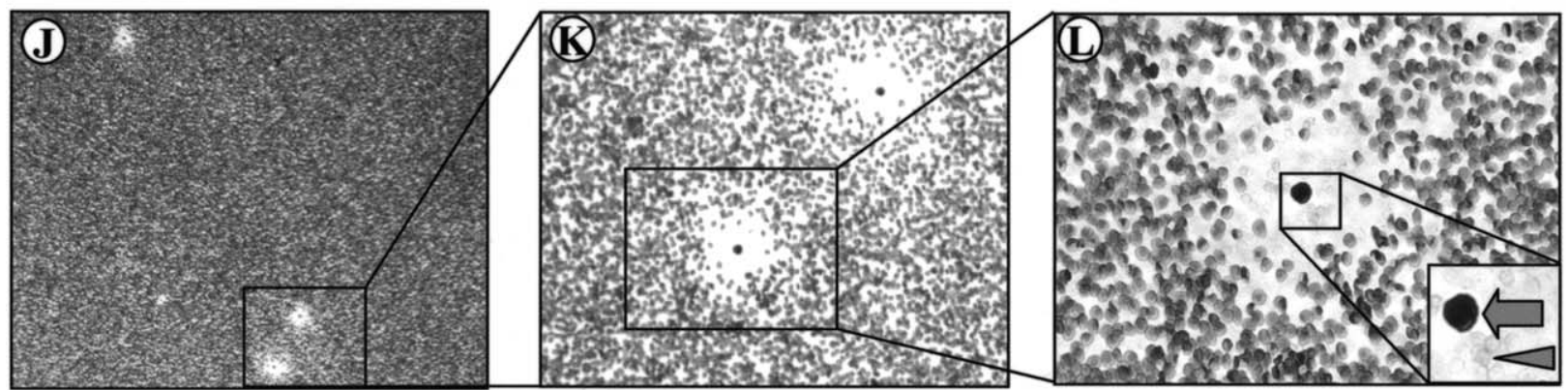



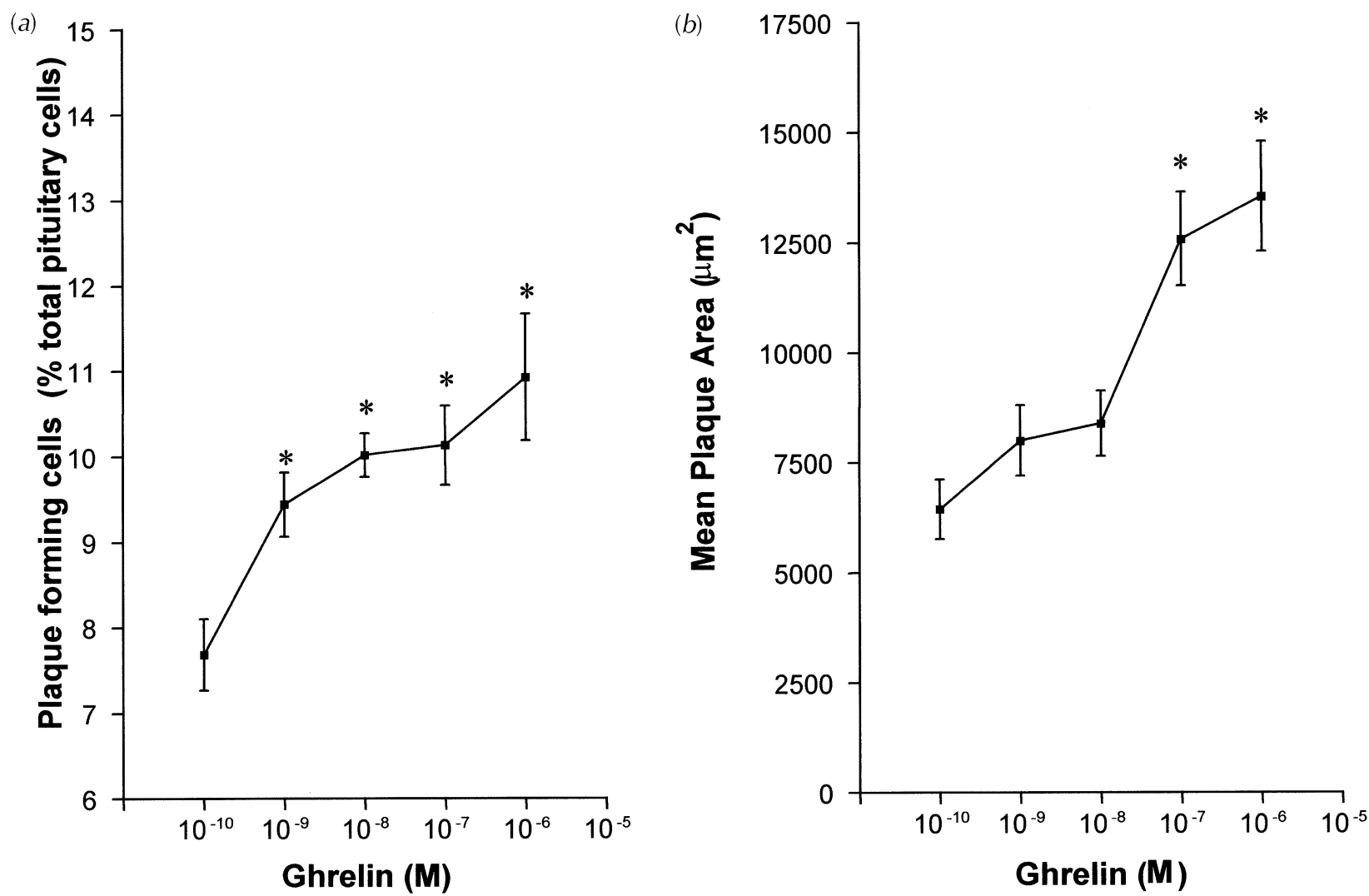

Figure 5 Plaques produced by $\mathrm{GH}$-secreting pituitary cells following a 60 -min incubation in $10^{-6}$ to $10^{-10} \mathrm{M}$ human ghrelin. (a) The relative number of plaque-forming cells and $(b)$ the size of the plaques produced. Values are means \pm S.E.M. $(n=4)$. Asterisks indicate values significantly different from the corresponding controls (number of plaque-forming cells in the controls, $8 \cdot 15 \pm 0 \cdot 33 \%(n=5)$; area of plaques formed in controls, $7360 \pm 390 \mu \mathrm{m}^{2}(n=5)(P<0 \cdot 05$, analysis of variance) $)$.

$20-100 \mu \mathrm{g} / \mathrm{kg}$ ), although the GH response was not doserelated (Kaiya et al. 2002). Human ghrelin was also found to be an effective GH secretagogue in 4-week-old Leghorn chicks at a dose of $10 \mu \mathrm{g} / \mathrm{kg}$ (Ahmed \& Harvey 2002). The plasma GH concentration in these birds was increased to the levels seen in birds injected with the same dose $(10 \mu \mathrm{g} / \mathrm{kg})$ of GHRH, although the GH response was less than that of GHRH on a molar basis and less than that produced by TRH (Ahmed \& Harvey 2002).

The results of the present in vivo studies show that ghrelin-induced GH secretion in chicks is dose-related, although the maximum in vivo response (approximately threefold increase in the plasma GH concentration) was induced by the $10 \mu \mathrm{g} / \mathrm{kg}$ dose, whilst the minimally effective dose was $1 \mu \mathrm{g} / \mathrm{kg}$. A similarly narrow doseresponse range has also been seen for ghrelin-induced in vivo GH secretion in rats (Seoane et al. 2000, Tolle et al. 2001). The in vivo GH response of chicks to GHRH is, like ghrelin, almost 'all-or-none' over the same dose range, whereas the in vivo GH response of chickens to TRH is demonstrable over four orders of magnitude (Harvey \& Scanes 1984).
The $\mathrm{ED}_{50}$ for human ghrelin-induced in vivo $\mathrm{GH}$ secretion in chicks (approximately $3.0 \mu \mathrm{g} / \mathrm{kg}$ ) is below the effective dose range of rat ghrelin in rats $(3-60 \mathrm{nmol} / \mathrm{kg}$ $(10-200 \mu \mathrm{g} / \mathrm{kg}))$; with a maximally effective dose of $12 \mathrm{nmol} / \mathrm{kg}(40 \mu \mathrm{g} / \mathrm{kg})$, Seone et al. 2000), but it is within the effective dose range of human ghrelin in humans $(0 \cdot 2-6 \cdot 6 \mu \mathrm{g} / \mathrm{kg}$; Peino et al. 2000, Takaya et al. 2000). The minimally effective dose of ghrelin in chicks in vivo $(1 \mu \mathrm{g} / \mathrm{kg})$ is also less than that in rats $(3 \mathrm{nmol} / \mathrm{kg} ; 10 \mu \mathrm{g} / \mathrm{kg}$; Seoane et al. 2000), although human ghrelin is an effective GH secretagogue in man at doses of 0.8 and $0.2 \mu \mathrm{g} / \mathrm{kg}$ (Peino et al. 2000, Takaya et al. 2000, Hataya et al. 2001). In vivo $\mathrm{GH}$ secretion in humans, therefore, appears to be more sensitive to ghrelin stimulation than in chickens and rats. The reduced GH responsiveness of chickens to human ghrelin is, however, unlikely to be due to the use of a heterologous secretagogue, since rat and chicken ghrelin are equally effective in rats at a dose of $20 \mu \mathrm{g} / \mathrm{kg}$ (Kaiya et al. 2002) and human and chicken ghrelin are equally effective in chicks at doses of $2-10 \mu \mathrm{g} / \mathrm{chick}$ (Kaiya et al. 2002). The in vivo GH response of Leghorn chicks to a maximally effective intravenous dose of ghrelin 
is also of shorter duration than that in mammals, since it only lasted for $20 \mathrm{~min}$ in chickens, whereas it lasts for at least 90 min in man (Takaya et al. 2000, Arvat et al. 2001) and for at least $40 \mathrm{~min}$ (Tolle et al. 2001) or $45 \mathrm{~min}$ in rats (Seoane et al. 2000).

It is also of interest that the in vivo GH-releasing activity of ghrelin in Leghorn chicks appears to be greater than that observed in broiler chicks by Kaiya et al. (2002), since human and chicken ghrelin were ineffective in broilers at a dose of $0.4 \mu \mathrm{g} / \mathrm{bird}$ (a dose of at least $4.0 \mu \mathrm{g} / \mathrm{kg}$ ). This is, however, likely to reflect a strain difference, since TRH is similarly more effective in inducing GH release in Leghorns than in broiler fowls (Harvey 1993b).

The $\mathrm{EC}_{50}$ for human ghrelin-induced $\mathrm{GH}$ secretion in chicks in vivo is also comparable with that for human GHRH in chickens (Harvey \& Scanes 1984), although it would appear to be less effective on a molar basis. Ahmed \& Harvey (2002) similarly found that the GH-releasing activity of ghrelin in chicks in vivo was less than that induced by human GHRH. This contrasts with humans, in whom ghrelin is far more effective than GHRH in vivo (Arvat et al. 2000, 2001, Di Vito et al. 2002), as in rats (Seoane et al. 2000, Tolle et al. 2001). Ghrelin is also reported to be less effective than GHRH in stimulating in vivo $\mathrm{GH}$ secretion in dogs (Bhatti et al. 2002), although Cella et al. (1995) found that hexarelin (a GH segretagogue receptor agonist) was a more potent $\mathrm{GH}$ secretagogue than GHRH. The relative effectiveness of GHRH and ghrelin in stimulating in vivo $\mathrm{GH}$ secretion may, nevertheless, be species specific.

The in vivo GH response of chickens to ghrelin is likely to be, at least partly, due to direct actions on pituitary somatotrophs. The dose-related GH responses of individual and dispersed pituitary cells to in vitro ghrelin treatment support this view. Indeed, because the pituitary cells were dispersed and geographically separated in the RHPA amongst oRBCs, the somatotroph responses to ghrelin must be due to direct effects on the GH-secreting cells, rather than to actions mediated through other pituitary cell types. Dose-dependent GH responses to ghrelin have also been established with dispersed rat pituitary cells (Kojima et al. 1999, 2001, Tolle et al. 2001, Yamazaki et al. 2002), in which the $\mathrm{EC}_{50}$ is also in the $10^{-8} \mathrm{M}$ range. The minimally effective dose of ghrelin in chickens in vitro $\left(10^{-9} \mathrm{M}\right)$ is, however, higher than that $\left(10^{-11} \mathrm{M}\right)$ required to provoke $\mathrm{GH}$ release in some studies with rat pituitary cells (Yamazaki et al. 2002), although it is comparable with that in other studies (Kojima et al. 1999). Other GH secretagogue receptor agonists also promote GH release from rat pituitary tissues (Locatelli et al. 1994) and a pituitary site of ghrelin action is undoubtedly involved, despite the finding by Pinilla et al. (2003) that ghrelin was ineffective in inducing $\mathrm{GH}$ release from the pituitaries of prepubertal rats at concentrations of $10^{-9}$ to $10^{-7} \mathrm{M}$, concentrations that were effective for GHRH.
The sensitivity of the in vitro $\mathrm{GH}$ response of dispersed chicken pituitary cells to ghrelin was comparable with the $\mathrm{GH}$ response to GHRH, although the responses were of lesser magnitude. Ghrelin-induced GH secretion from chicken pituitary cells is thus likely to be mediated by a rapid degranulation of the somatotrophs, as demonstrated for other GH secretagogues (Hull et al. 2000). The action of ghrelin is, however, accompanied by an increase in the number of somatotrophs induced to release $\mathrm{GH}$ and by an increase in the amount of $\mathrm{GH}$ released by individual somatotrophs. These somatotroph responses are very similar to the responses of chicken pituitary cells to GHRH stimulation, as revealed by RHPA analysis (Morpurgo \& Porter 1995, Porter et al. 1995, Dean et al. 1997). These results are, however, the first to demonstrate ghrelininduced GH secretion from individual somatotrophs for any species.

While ghrelin may have pituitary sites of action in mammals, the in vivo $\mathrm{GH}$ responses to ghrelin in mammals is thought to be largely mediated through the central nervous system (CNS) (Date et al. 2000, Wren et al. 2000, 2002, Tamura et al. 2002, Pinilla et al. 2003). Indeed, ghrelin inhibits somatostatin (SRIF) release (Tolle et al. 2001, Seoane et al. 2003) and increases GHRH tone (Tannenbaum \& Bowers 2001, Tannenbaum et al. 2003), either of which would augment its pituitary action. Ghrelin may have similar actions in chickens, since synthetic ligands of the GH secretagogue/ghrelin receptor increase GH release at pituitary and extrapituitary sites (Geris et al. 1998, 2001). The possible contribution of SRIF disinhibition or GHRH stimulation or GHRH synergy (Takaya et al. 2000, Arvat et al. 2001, Hataya et al. 2001) to ghrelin-induced GH secretion in birds is, however, unknown. An extrapituitary action of ghrelin that suppresses the in vivo GH response of chicks to ghrelin is, however, suggested by the observation that the GH response to ghrelin in vitro (over four orders of magnitude) differed from the in vivo response (over two orders of magnitude). This contrasts with the in vivo GH-releasing activity of TRH in chickens, which is known to be partly due to stimulatory actions at CNS sites (Harvey et al. 1990). Although this also contrasts with the central actions of $\mathrm{GH}$ secretagogue receptor agonists in chickens (Geris et al. 2001), both stimulatory and inhibitory actions of GH secretagogues on SRIF release have been observed in rats (Bluet-Pajot et al. 2001).

In summary, these results demonstrated that ghrelin is a dose-related GH secretagogue in immature chickens, directly stimulating the number of somatotrophs secreting $\mathrm{GH}$ and the amount of $\mathrm{GH}$ released from individual somatotrophs.

\section{Acknowledgements}

The authors would like to thank Dr T E Porter (Department of Avian and Poultry Science, University of Maryland) for 
the $\mathrm{GH}$ antisera, raised against recombinant chicken $\mathrm{GH}$, and Amy Tse and Andy Lee (Department of Pharmacology, University of Alberta) for assistance with the RHPA methodology.

\section{Funding}

M-L B was in receipt of a studentship from the Alberta Heritage Foundation for Medical Research. This work was supported by an operating grant from the National Sciences and Engineering Research Council of Canada.

\section{References}

Ahmed S \& Harvey S 2002 Ghrelin: a hypothalamic GH-releasing factor in domestic fowl (Gallus domesticus). Journal of Endocrinology 172 117-125.

Arvat E, Di Vito L, Broglio F, Papotti M, Muccioti G, Dieguez C, Casanueva FF, Deghenghi R, Camanni F \& Ghigo E 2000 Preliminary evidence that ghrelin, the natural GH secretagogue (GHS) receptor ligand, strongly stimulates $\mathrm{GH}$ secretion in humans. Journal of Endocrinological Investigation 23 493-495.

Arvat E, Maccario M, Di Vito L, Broglio F, Benso A, Gottero C, Papotti M, Muccioli G, Dieguez C, Casanueva FF, Deghenghi R, Camanni F \& Ghigo E 2001 Endocrine activities of ghrelin, a natural growth hormone secretagogue (GHS), in humans: comparison and interactions with hexarelin, a nonnatural peptidyl GHS, and GH-releasing hormone. Journal of Clinical Endocrinology and Metabolism 86 1169-1174.

Bhatti SF, De Vliegher SP, Van Ham L \& Kooistra HS 2002 Effects of growth hormone-releasing peptides in healthy dogs and in dogs with pituitary-dependent hyperadrenocorticism. Molecular and Cellular Endocrinology 197 97-103.

Bluet-Pajot MT, Tolle V, Zizzari P, Robert C, Hammond C, Mitchell V, Beauvillain JC, Viollet C, Epelbaum J \& Kordon C 2001 Growth hormone secretagogue and hypothalamic networks. Endocrine 14 1-8.

Cella SG, Locatelli V, Poratelli M, De Gennaro Colonna V, Imbimbo BP, Deghenghi R \& Muller EE 1995 Hexarelin, a potent GHRP analogue: interactions with GHRH and clonidine in young and aged dogs. Peptides 16 81-86.

Date Y, Murkami N, Kojima M, Kuroiwa T, Matsukura S, Kangawa K \& Nakazato M 2000 Central effects of a novel acylated peptide, ghrelin, on growth hormone release in rats. Biochemical and Biophysical Research Communications 275 477-480.

Dean CE, Piper M \& Porter TE 1997 Differential responsiveness of somatotrophs to growth hormone-releasing hormone and thyrotropin-releasing hormone during chicken embryonic development. Molecular and Cellular Endocrinology 132 33-41.

Di Vito L, Broglio F, Benson A, Gottero C, Prodam F, Papotti M, Muccioli G, Dieguez C, Casanueva FF, Deghenghi R, Ghigo E \& Arvat E 2002 The GH-releasing effect of ghrelin, a natural GH secretagogue, is only blunted by the infusion of exogenous somatostatin in humans. Clinical Endocrinology 56 643-648.

Frawley LS \& Neill JD 1984 A reverse hemolytic plaque assay for microscopic visualization of growth hormone release from individual cells: evidence for somatotrope heterogeneity. Neuroendocrinology 39 484-487.

Geris KL, Hickey GH, Berghman LR, Visser TJ, Kuhn ER \& Darras VM 1998 Pituitary and extrapituitary action sites of the novel nonpeptidyl growth hormone (GH) secretagogue L-692,429 in the chicken. General and Comparative Endocrinology 111 186-196.
Geris KL, Hickey GJ, Vandergohte A, Kuhn ER \& Darras VM 2001 Synthetic growth hormone secretagogues control growth hormone secretion in the chicken at pituitary and hypothalamic levels. Endocrine 14 67-72.

Harvey S 1993a Growth hormone secretion in poikilotherms and homeotherms. In The Endocrinology of Growth, Development and Metabolism in Vertebrates, pp 151-182. Eds PKT Pang, M Schriebman \& CG Scanes. New York: Academic Press

Harvey S 1993b Hypophysiotropic control of growth hormone secretion and its feed-back regulation: an update. In Avian Endocrinology, pp 11-28. Ed. PJ Sharp. Bristol: Society for Endocrinology.

Harvey S 1999 GHRH: a growth hormone-releasing factor in birds? In Neural Regulation in the Vertebrate Endocrine System, pp 60-84. Eds S Prasada Rao \& RE Peter. New York: Kluwer Academic/Plenum Publishers.

Harvey S \& Scanes CG 1984 Comparative stimulation of growth hormone secretion in anaesthetized chickens by human pancreatic growth hormone-releasing factor (hpGRF) and thyrotropin-releasing hormone (TRH). Neuroendocrinology 39 314-320.

Harvey S, Scanes CG, Chadwick A \& Bolton NJ 1978 The effect of thyrotropin-releasing hormone (TRH) and somatostatin (GHRIH) on growth hormone and prolactin secretion in vitro and in vivo in the domestic fowl (Gallus domesticus). Neuroendocrinology 26 249-260.

Harvey S, Lea RW \& Ahene C 1990 Central action of thyrotrophinreleasing hormone on growth hormone secretion in domestic fowl. Journal of Endocrinology 126 83-88.

Hataya Y, Akamizu T, Takaya K, Kanamoto N, Ariyasu H, Saijo M, Moriyama K, Shimatsu A, Kojima M, Dangawa K \& Nakao K 2001 A low dose of ghrelin stimulates growth hormone $(\mathrm{GH})$ release synergistically with GH-releasing hormone in humans. Journal of Clinical Endocrinology and Metabolism 86 4552-4555.

Hull KL, Murphy A \& Harvey S 2000 Avian somatotrophs: differentiation, morphology, distribution, and regulation. Canadian Journal of Physiology and Pharmacology 78 994-1002.

Kaiya H, van der Geyten S, Kojima M, Hosoda H, Kitajima Y, Matsumoto M, Geelissen S, Darras VM \& Kangawa K 2002 Chicken ghrelin: purification, cDNA cloning, and biological activity. Endocrinology 143 3454-3463.

Kojima M, Hosoda H, Date Y, Nakazato M, Matsuo H \& Kangawa K 1999 Ghrelin is a growth-hormone-releasing acylated peptide from stomach. Nature 402 656-660.

Kojima M, Hosoda H, Matsuo H \& Kangawa K 2001 Ghrelin: discovery of the natural endogenous ligand for the growth hormone secretagogue receptor. Trends in Endocrinology and Metabolism 12 $118-122$.

Locatelli V, Grilli R, Torsello A, Cella SG, Wehrenberg WB \& Muller EE 1994 Growth hormone-releasing hexapeptide is a potent stimulator of growth hormone gene expression and release in the growth hormone-releasing hormone-deprived infant rat. Pediatric Research 36 169-174.

Morpurgo B \& Porter TE 1995 Cellular basis for gender-dependent differences in growth hormone secretion in young chickens: analysis using reverse hemolytic plaque assays. Growth, Development, Aging $5925-30$

Neill JD \& Frawley S 1983 Detection of hormone release from individual cells in mixed populations using a reverse hemolytic plaque assay. Endocrinology 112 1135-1137.

Peino R, Baldelli R, Rodriquez-Garcia J, Rodriquez-Segade S, Kojima M, Kangawa K, Arvat E, Ghigo E, Diequez C \& Casanueva FF 2000 Ghrelin-induced growth hormone secretion in humans. European Journal of Endocrinology 143 R11-R14.

Pinilla L, Barreiro ML, Tena-Sempere M \& Aguilar E 2003 Role of ghrelin in the control of growth hormone secretion in prepubertal rats: interactions with excitatory amino acids. Neuroendocrinology $\mathbf{7 7}$ 83-90. 
Porter TE, Couger GS, Dean CE \& Hargis BM 1995 Ontogeny of growth hormone $(\mathrm{GH})$-secreting cells during chicken embryonic development: initial somatotrophs and responsive to GH-releasing hormone. Endocrinology 136 1850-1956.

Robberecht W, Andries M \& Denef C 1992 Stimulation of prolactin secretion from rat pituitary by luteinizing hormone-releasing hormone: evidence against mediation by angiotensin II acting through a (Sar1-Ala8)-angiotensin II-sensitive receptor. Neuroendocrinology 56 185-194.

Scanes CG \& Harvey S 1984 Stimulation of growth hormone secretion by human pancreatic growth-hormone-releasing factor and thyrotropin-releasing hormone in anesthetized chickens. General and Comparative Endocrinology 56 198-203.

Schwartz J 2000 Intercellular communication in the anterior pituitary. Endocrine Reviews 21 488-513.

Schwartz J 2001 Intrapituitary interactions: another level of endocrine regulation. Clinical and Experimental Pharmacology and Physiology 28 237-238.

Seoane LM, Tovar S, Baldelli R, Arvat E, Ghigo E, Casanueva FF \& Dieguez C 2000 Ghrelin elicits a marked stimulatory effect on GH secretion in freely moving rats. European Journal of Endocrinology 143 R7-R9.

Seoane LM, Lopez M, Tovar S, Casanueva FF, Senaris R \& Dieguez C 2003 Agouti-related peptide, neuropeptide Y, and somatostatinproducing neurons are targets for ghrelin actions in the rat hypothalamus. Endocrinology 144 544-551.

Takaya K, Ariyasu H, Kanamoto N, Iwakura H, Yoshimoto A, Harada M, Mori K, Komatsu Y, Usui T, Shimatsu A, Ogawa Y, Hosoda K, Akamizu T, Kojima M, Kangawa K \& Nakao K 2000 Ghrelin strongly stimulates growth hormone $(\mathrm{GH})$ release in humans. Journal of Clinical Endocrinology and Metabolism 85 4908-4911.

Tamura H, Kamegai J, Shimizu T, Sugihara H \& Oikawa S 2002 Ghrelin stimulates $\mathrm{GH}$ but not food intake in arcuate nucleus ablated rats. Endocrinology 143 3268-3275.
Tannenbaum GS \& Bowers CY 2001 Interactions of growth hormone secretagogues and growth hormone-releasing hormone/somatostatin. Endocrine 14 21-27.

Tannenbaum GS, Epelbaum J \& Bowers CY 2003 Interrelationship between the novel peptide ghrelin and somatostatin/growth hormone-releasing hormone in regulation of pulsatile growth hormone secretion. Endocrinology 144 967-974.

Tilemans D, Andries M \& Denef C 1992 Luteinizing hormonereleasing hormone and neuropeptide $\mathrm{Y}$ influence deoxyribonucleic acid replication in three anterior pituitary cell types. Evidence for mediation by growth factors released from gonadotrophs. Endocrinology 130 882-894.

Tolle V, Zizzari P, Tomasetto C, Rio M-C, Epelbaum J \& Bluet-Pajor M-T 2001 In vivo and in vitro effects of ghrelin/motilin-related peptide on growth hormone secretion in the rat. Neuroendocrinology 73 54-61.

Wren AM, Small CJ, Ward HL, Murphy KG, Dakin CL, Taheria S, Kennedy AR, Roberts GH, Morgan DGA, Ghatei MA \& Bloom SR 2000 The novel hypothalamic peptide ghrelin stimulates food intake and growth hormone secretion. Endocrinology 141 4325-4328.

Wren AM, Small CJ, Fribbens CV, Neary NM, Ward HL, Seal LJ, Ghatei MA \& Bloom SR 2002 The hypothalamic mechanism of the hypophysiotropic action of ghrelin. Neuroendocrinology $\mathbf{7 6}$ 316-324.

Yamazaki M, Nakamura K, Kobayashi H, Matsubara M, Kangawa K \& Sakai T 2002 Regulational effect of Ghrelin on growth hormone secretion from perifused rat anterior pituitary cells. Journal of Neuroendocrinology 14 156-162.

Received 15 May 2003

Accepted 17 July 2003 